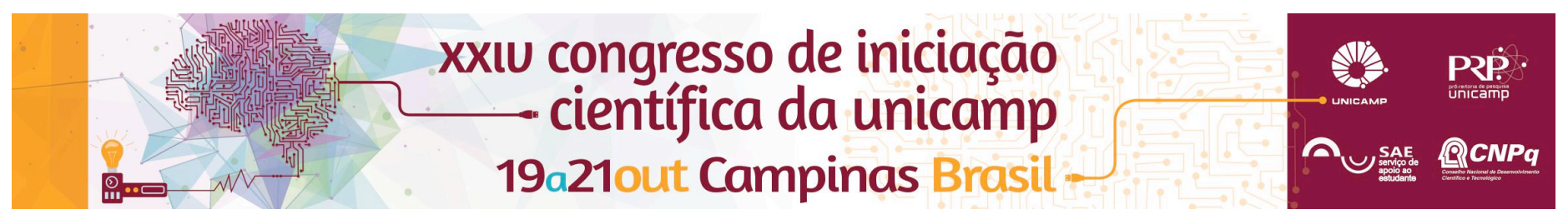

\title{
INFLUÊNCIA DA ADIÇÃO DE EVA NAS PROPRIEDADES MECÂNICAS DO CONCRETO DE CIMENTO PORTAND
}

\author{
Felipe S. Cruz*, Carlos E. M. Gomes
}

\section{Resumo}

O presente projeto de iniciação científica teve por objetivo apresentar ao aluno de graduação as principais propriedades mecânicas dos compósitos cimentícios modificados com polímero, especialmente, o Acetato de Vinila e Etileno (EVA), o acetato de vinila-vinil versatato (Va/VeoVa) e o estireno-butadieno (SB). Sabe-se que o uso de polímeros pode melhorar as propriedades das argamassas e concreto de cimento Portland tais como, resistência mecânica, permeabilidade, aderência, abrasão e retração. No entanto, esta tecnologia tem sido muito empregada apenas na produção das argamassas colantes devido à característica adesiva de certos polímeros. Ainda, verifica-se na literatura que a adição de polímeros nos compósitos cimentícios incrementa sua durabilidade. Dessa forma, a presente pesquisa realizou a analise dos benefícios da adição do três tipos de polímeros nas propriedades mecânicas dos compósitos cimentícios, especialmente a resistência à compressão e tração na flexão de concretos de cimento Portland.

\section{Palavras-chave:}

EVA, Polímero, Concreto.

\section{Introdução}

No que se refere aos materiais, as matrizes de cimento modificadas com polímero divergem das convencionais apenas pela adição de um monômero ou polímero, que podem estar disperso ou não em solução aquosa, para realização de uma polimerização "in situ".

Basicamente, estes compósitos são materiais em que a fase aglomerante é composta por dois componentes ativos: o cimento Portland e a dispersão de um monômero ou polímero em água. Em outras palavras, tais matrizes cimentícias modificadas com polímero, são produtos da associação de um composto inorgânico (cimento) e um composto orgânico (polímero) que possui uma estrutura que consiste no gel do cimento e as microfibras do polímero. Consequentemente, incrementos em diversas propriedades são observados: Resistência mecânica; Aumento de tenacidade; Consistência; Hidrofobicidade; Incorporação de Ar; Retração por Secagem.

Este projeto teve por objetivo o estudo da modificação de compostos cimentícios por meio da adição de polímero redispersível. Com ênfase no estudo do EVA.

\section{Resultados e Discussão}

A influência do polímero EVA, SB e VA/VEOVA nas propriedades do concreto foi investigada conforme procedimentos descritos nas normas: NBR 7222 Concreto e argamassa - Determinação da resistência à tração por compressão diametral de corpos de prova cilíndricos ou NBR 12142 - Concreto - Determinação da resistência à tração na flexão de corpos de prova prismáticos; NBR 7215 - Cimento Portland Determinação da Resistência à compressão e NBR 8522 - Concreto - Determinação do módulo de deformação estática.

Com relação ao EVA, observando as tabelas, observa-se que as amostras com $2,5 \%$ de polímero em sua constituição apresentam uma piora significativa no quesito de resistência mecânica a compressão em comparação a amostra controle; concomitante a isso, nota-se que com o aumento de mais $2,5 \%$ de EVA há uma perda na compressão, principalmente se o teste for realizado nas duas pontoas do material.

Tabela 1. Comparação entre os resultados aos ensaios.

\begin{tabular}{|c|c|c|c|}
\hline Corpo & Flexão & Tração na Flexão & $\begin{array}{c}\text { Resistência } \\
\text { Compressão }\end{array}$ \\
\hline Unidade & $\mathrm{N}$ & $\mathrm{N}$ & $\mathrm{MPa}$ \\
\hline EVA 2,5\% & 372.7 & 2720.4 & 44.1 \\
\hline EVA 5\% & 382.5 & 2792.0 & 39.2 \\
\hline Controle & 378.5 & 2749.8 & 40.9 \\
\hline
\end{tabular}

\section{Conclusões}

O presente projeto contemplou, assim, inovações tecnológicas referentes a utilização de argamassas e concretos com diferentes teores de polímeros, com ênfase no EVA. Sabe-se que estas substancias podem ser muito benéficas em alguns casos de aplicação no setor da construção civil, mesmo que sofram com muito preconceito e com o preço.

Os benefícios que o projeto tem promovido são inúmeros, como a compreensão do conceito e desempenho de materiais compósitos, a compreensão das propriedades físicas dos materiais de construção e, principalmente a compreensão das propriedades mecânicas: tração na flexão, compressão e outras. Vale lembrar que o primeiro contato com adições é essencial para o aprimoramento tecnológico, principalmente com relação as novidades que sempre aparecem no mercado e que, devido ao pouco conhecimento, geram o atraso no desenvolvimento.

\section{Agradecimentos}

Gostaria de Agradecer ao meu Orientador, Prof. Dr. Carlos Eduardo Marmorato Gomes, a Instituição que promoveu essa possibilidade de desenvolvimento do projeto e ao meu colega Caio Batista Carra, que me ajudou no desenvolvimento do projeto e em sua execução.

GOMES, Carlos Eduardo Marmorato. Analyses of microstructural properties of VA/VeoVA copolymer modified cement pastes. Polímeros vol.15 no.3 São Carlos July/Sept. 2005 